\title{
Pretend Play pada Anak Autism Spectrum Disorder (ASD) ditinjau dari Secure Attachment
}

\author{
Risvi Rayhani', Endang Widyorini' ${ }^{2}$, Maria Yang Roswita ${ }^{3}$ \\ 1,2,3Fakultas Psikologi Universitas Katolik Soegijapranata \\ Jl. Pawiyatan Luhur Sel. IV, No.1, Semarang 50234, Jawa Tengah \\ 1risvirayhani.rr@gmail.com
}

Article History:

Received

2021-10-15

Review

2021-12-11

Revised

2021-12-13

Accepted

2021-12-14

Published

2021-12-28
Abstract. This study aimed to find out and provide an overview of the relationship between the intensity of secure attachment and pretend play in children with ASD. The participants of this study were two girls and three boys between 6-12 years old with ASD. This study used correlational methods. The researcher observed the children while they were playing with a checklist and interviewed their parents to collect the data for this research. Pretend play Skills are seen in three main things, frequency, duration and variety of play. The results of Spearman Rho provide that there was a significant correlation between secure attachment and pretend play (rho $=0.975$ $; p=0.005$ ).

Keywords: Pretend Play of children with Autism Spectrum Disorder; Secure Attachment

Abstrak. Penelitian ini bertujuan untuk menemukan dan memberikan sebuah gambaran mengenai hubungan antara secure attachment dan pretend play pada anak dengan ASD. Partisipan dalam penelitian ini adalah dua anak perempuan dan tiga anak lakilaki dengan rentang usia 6-12 tahun yang memiliki gangguan ASD. Penelitian ini menggunakan metode korelasi. Peneliti mengumpulkan data penelitian dengan melakukan observasi pada anak selama mereka bermain dengan menggunakan check list dan melakukan wawancara dengan orangtua. Kemampuan bermain pretend play dilihat dari tiga hal utama yakni frekuensi, durasi dan variasi permainan. Hasil uji Spearman Rho menunjukkan bahwa terdapat korelasi yang signifikan antara pretend play dan secure attachment (rho $=0.975 ; p=0.005$ ).

Kata kunci: Pretend Play pada anak dengan ASD; Secure Attachment.

\section{Pendahuluan}

Jerome Bruner (Tedjasaputra, 2001 dan Frost, 2008) mengemukakan bermain merupakan sarana mengembangkan sisi kreativitas dan fleksibilitas. Bermain juga sarana mengeksplorasi dan menguasai kemampuan yang dibutuhkan saat usia dewasa. Anakanak mulai menggunakan objek sebagai sarana untuk menyelesaikan masalah dan ketika permainan melibatkan orang dewasa dapat mengajarkan anak-anak mengenai konvensi dan simbol sosial. Goldstein (2012) menambahkan hal yang terpenting saat bermain adalah makna bermain pada anak-anak dan bukanlah hasil akhir. Melalui aktivitas bermain juga membantu dalam mengembangkan beberapa fungsi perkembangan, antara 
lain perkembangan emosi, kognitif, fisik, kompetensi sosial, bahasa serta disaat bermain anak mengembangkan diri membentuk kepribadian masing-masing (Runcan, Petracovschi, \& Borca, 2012) dan (Lifter et al. 2011).

Anak-anak yang melakukan aktivitas bermain tidak hanya anak dengan perkembangan normal, namun juga bagi anak-anak dengan kebutuhan khusus. Anak dengan ASD salah satunya, meskipun pola dan perilaku bermain berbeda (Kanner dalam Kasari et al, 2013), karena pola dan perilaku bermain mengalami keterlambatan (Frost, 2008). Keterlambatan dan kekurangan ada pada domain kognisi sosial yang meliputi beberapa tahap perkembangan bahasa, emosi, sosial dan kognitif. Anak dengan ASD sering menunjukkan cara bermain dengan menggunakan objek atau alat permainan secara repetitif, terbatas, kaku, cara-cara yang tidak simbolik serta berpusat pada kekhasan sensorik atau pada pemahaman fisik (Doody and Merz, 2013, Benson et al, 2006). Anak dengan ASD juga kurang dapat menunjukkan kemampuan yang kompleks saat bermain dan belum dapat memahami dengan baik kemampuan sebenarnya untuk bermain dengan teman sebaya (kognitif, psikomotorik dan menciptakan hubungan) (Perrin dalam Besio, S., Bulgarelli, D., Stancheva-Popkostadinova, V, 2007).

Anak dengan ASD menunjukkan ketidakmampuan dalam bentuk permainan pretend play (Frost, 2008). Stagnitti \& Unsworth (Chan, Chen, Feng, Lee, \& Chen, 2016)menjelaskan bahwa pretend play didefinisikan sebagai permainan yang terdiri dari permainan imajinatif konvensional dan permainan simbolik. Szabo juga mengemukakan pendapat yang sama, yaitu dalam pretend play dapat melihat sisi eksplorasi, penggunaan objek sesuai dengan fungsi, kreativitas serta proses imitasi (Szabó, 2014). Bergen (2002) mengemukakan pretend play erat kaitannya dengan kemampuan kognitif, kemampuan sosial dan kemampuan emosi anak. Apabila anak tidak dapat melakukan pretend play, hal ini dapat berpengaruh terhadap kemampuan kognitif, kemampuan sosial dan kemampuan emosi anak (ekspresi emosi, mengontrol emosi, menirukan emosi serta memahami perkembangan emosi yang lainnya). Anak juga akan kesulitan untuk memahami emosi dalam diri dan emosi orang lain. Bergen juga menambahkan bahwa pretend play membantu anak-anak dalam kemampuan perencanaan, negosiasi, pemecahan masalah dan pencapaian tujuan. Sejalan dengan pendapat Bergen, penelitian yang dilakukan oleh Jorgenson juga mengemukakan bahwa fasilitas yang diberikan untuk pretend play dapat membantu anak dengan ASD pada kualitas pretend play (kreativitas dan imajinatif, kemampuan bahasa dan sosial) (Jorgenson, 2017). 
Salah satu hal yang menjadi kesulitan anak dengan ASD dalam pretend play adalah mengenai spontanitas. Oleh karena itu, anak dengan ASD memerlukan bantuan berupa modelling dan prompting. (Ungerer \& Sigman, 1981; Riguet, Taylor, Benarogya, \& Klein, 1981; Lewis \& Boucher, 1988; Stahmer, 1995 (Szabó, 2014)). Sebagai tambahan dalam video modelling diberikan variasi verbal dan beberapa aktivitas bermain yang dapat membantu dan mendukung interaksi bermain anak dengan ASD. Orangtua atau pengasuh dapat juga menjadi sumber modelling dan prompting untuk anak dengan ASD. Rasa percaya pada orangtua atau pengasuh dapat membantu anak-anak saat bermain pretend play dan hal ini merupakan salah satu bentuk dari secure attachment. Anak-anak yang merasa aman dan nyaman, terlebih pada anak dengan ASD mereka dapat mengembangkan keterikatan dengan orangtua atau pengasuh dan hal ini berkontribusi pada hasil bermain yang lebih baik (Naber et al. 2007; Rutgers et al. 2004).

Secure attachment merupakan support yang baik bagi anak ASD saat melakukan pretend play, meskipun spontanitas untuk melakukan pretend play ini belum terbentuk. Rasa aman dan nyaman yang dirasakan anak membantu saat bermain, sehingga permainan jauh lebih lama (durasi permainan lebih lama) dibandingkan dengan anak dengan ASD tanpa secure attachment (Naber, et al., 2008). Secure attachment sendiri merupakan keterikatan dan adanya hubungan yang baik antara pengasuh atau orangtua dengan anak, sehingga anak dapat mengembangkan rasa percaya, rasa aman untuk mengeksplorasi apa yang ada di lingkungan sekitar. Rasa aman ini menumbuhkan rasa percaya diri, anak menjadi lebih tangguh serta keterampilan adaptif yang lebih baik (Gearity, Ainsworth et al, Thompson, Kestenbaum et al, dalam Malekpour, 2007).

Anak dengan ASD yang mengembangkan rasa aman dan percaya pada orangtua atau pengasuh dapat mengoptimalkan peluang untuk memulai mengeksplorasi lingkungan yang ada di sekitarnya. Lingkungan yang dieksplorasi adalah lingkungan yang aman dan mendukung. Anak-anak dengan secure attachment dengan sosok ibu menunjukkan perilaku bermain yang lebih baik, lebih kompleks, beragam (variasi permainan) dan juga pada saat melakukan permainan sendiri. Selain rasa percaya, Ainsworth dkk (Meins, 1997) mengatakan secure attachment juga dapat dilihat dari dimensi yang lain yaitu kedekatan, kepercayaan, kemandirian, suportif, mempertahankan hubungan dan resolusi konflik. Kedekatan meliputi rasa dekat secara emosional anak dengan orangtua. Kepercayaan merupakan rasa percaya anak terhadap orangtua dan orang-orang di sekitar dalam menjalin interaksi sosial. Kemandirian meliputi sikap anak yang mulai mandiri dan merasa tidak tergantung dengan sosok lekat dalam hal ini sosok orangtua. Secure 
attachment juga memberikan rasa aman dan nyaman kepada anak sebagai bentuk dukungan orangtua dan lingkungan sekitar. Saat merasa aman anak juga mengembangkan keinginan yang baik untuk mempertahankan hubungan dengan orangtua dan lingkungan hal ini mendukung saat proses bermain berlangsung anak dapat bertahan lama. Melalui secure attachment anak juga memiliki pandangan yang positif terhadap orangtua dan lingkungan dalam menyelesaikan permasalahannya.

Anak-anak yang merasa secure mengenal kebutuhannya secara jelas dan merasakan kepedulian orangtua. Anak-anak merasa yakin bahwa orangtua adalah sosok yang dekat, sensitif dan responsif. Kualitas hubungan antara anak dan orangtua juga jauh dari rasa tertekan, mempunyai kualitas yang baik, merasa bahagia dan penuh dengan kesenangan (George, 2014).

Penelitian sebelumnya mengenai kontribusi secure attachment saat diberikan prosedur bermain SSP (strange situation procedure) menunjukkan bahwa sekitar 50\% anak-anak yang mempunyai secure attachment pada ibu dapat mengendalikan kesulitan akan perpisahan dengan sosok lekat. Anak-anak ASD ini mengendalikan kesulitan dengan kontak mata dan melakukan gerakan stereotip seperti mengepakkan tangan dan menggoyangkan tangan. Kontak mata dan pemahaman anak pada komunikasi ibu merupakan bentuk frekuensi seberapa sering anak-anak menjalin interaksi dengan orangtua. Anak-anak ASD yang mempunyai secure attachment juga menunjukkan bahwa sensitivitas dan responsif dibandingkan pada anak ASD yang mempunyai kelekatan tidak aman (Crowell, Keluskar, \& Gorecki, Parenting Behavior and The Development of Children with Autism Spectrum Disorder, 2018). Naber (2008) dalam penelitiannya mengungkapkan bahwa anak-anak dengan ASD usia pra sekolah dengan secure attachment menunjukkan level yang tinggi dalam bermain dan dapat menghabiskan waktu lebih lama dibandingkan dengan anak-anak ASD yang tidak memiliki secure attachment, bahkan setelah ada kontrol dari perbedaan usia dan perbedaan perkembangan.

Berdasarkan penjelasan yang telah disebutkan diatas maka hipotesis yang diajukan dalam penelitian ini adalah terdapat hubungan antara secure attachment dan pretend play pada anak dengan ASD.

\section{Metode}

Partisipan dalam penelitian ini adalah lima anak ASD dengan kriteria usia berkisar 6-12 tahun dan sudah bersekolah, partisipan berjenis kelamin tiga laki-laki dan dua perempuan dengan kategori mildly-moderately autistic. Hal ini ditunjukkan pada tabel 1, skrining awal pada penelitian ini yaitu dengan menggunakan skala CARS (Childhood 
Autism Rating Scale), selanjutnya orangtua mengisi kesediaan untuk terlibat dalam penelitian melalui lembar inform consent. Sedangkan alat ukur dalam penelitian yaitu check list yang disusun berdasarkan dimensi pretend play dan secure attachment. Observasi dilakukan dengan memodifikasi penelitian Campbell dkk (2017) untuk melihat frekuensi, durasi dan juga variasi dalam pretend play. Frekuensi dilihat dari seberapa sering partisipan memainkan suatu permainan dan durasi dilihat dari berapa lama partisipan memainkan suatu permainan. selain itu variasi dilihat dari jenis permainan apa yang paling sering dimainkan. Secure attachment dilihat dari seberapa sering anak dengan ASD dan ibu melakukan interaksi, baik secara verbal maupun nonverbal. Validitas alat ukur dalam penelitian ini dinilai oleh tiga orang profesional dalam bidang psikologi dan dihitung menggunakan rumus Aiken's V. Hasil uji validitas menunjukkan bahwa item-item yang digunakan sebagai pedoman observasi memiliki validitas yang tinggi. Reliabilitas penelitian antar rater (interrater reliability) dilakukan oleh tiga orang mahasiswa magister profesi psikologi dan hasilnya diuji dengan Spearman Rho. Uji reliabilitas menunjukkan hasil yang reliabel dari ketiga rater. Penelitian ini menggunakan data dari rater satu, karena penilaian rater satu lebih stabil daripada kedua rater lainnya.

Tabel 1

Skor CARS tiap partisipan

\begin{tabular}{cc}
\hline Partisipan & Skor CARS \\
\hline Partisipan 1 & 31 \\
Partisipan 2 & 34 \\
Partisipan 3 & 31,5 \\
Partisipan 4 & 36,5 \\
Partisipan 5 & 36,5 \\
\hline
\end{tabular}

\section{Hasil}

Hasil perhitungan SPSS menunjukkan terdapat hubungan antara secure attachment dengan pretend play (Frekuensi + durasi) yaitu (rho $=0.975 ; p=0.005$ ), hasil lain pada tabel menyatakan bahwa terdapat hubungan antara secure attachment dan variasi permainan (yaitu (rho $=0.973 ; p=0.005$ ) .

Tabel 2

Hasil korelasi secure attachment dengan pretend play (frekuensi + durasi), serta variasi permainan

\begin{tabular}{|c|c|c|c|c|}
\hline \multirow{2}{*}{\multicolumn{2}{|c|}{ Secure attachment }} & \multicolumn{2}{|c|}{ Intensitas Pretend Play } & \multirow[b]{2}{*}{ Variasi } \\
\hline & & Frekuensi & Durasi & \\
\hline Koefisien korelasi & 1,000 & ,395 &, $975^{* *}$ &, $973^{* *}$ \\
\hline \multicolumn{5}{|c|}{ Intensitas PP $=, 975^{* *}$} \\
\hline
\end{tabular}


Dengan demikian hipotesis penelitian yang berbunyi "Ada hubungan antara secure attachment dan pretend play pada anak dengan ASD" dapat diterima. Sedangkan pada Tabel 3 di bawah menampilkan variasi apa saja permainan yang ditunjukkan oleh tiap partisipan.

Tabel 3

Variasi Permainan

\begin{tabular}{ccll}
\hline Partisipan & Variasi & \multicolumn{1}{c}{ Keterangan } & $\begin{array}{l}\text { Jenis Permainan yang } \\
\text { Paling Lama Durasinya }\end{array}$ \\
\hline Partisipan 1 & 3 & Helikopter, memasak, dokter & Helikopter \\
Partisipan 2 & 2 & Masak, kedokteran & Alat memasak \\
Partisipan 3 & 2 & Kedokteran, masak & Alat pancing \\
Partisipan 4 & 1 & Masak & Alat Pancing \\
Partisipan 5 & 1 & Pertukangan & Pertukangan \\
\hline
\end{tabular}

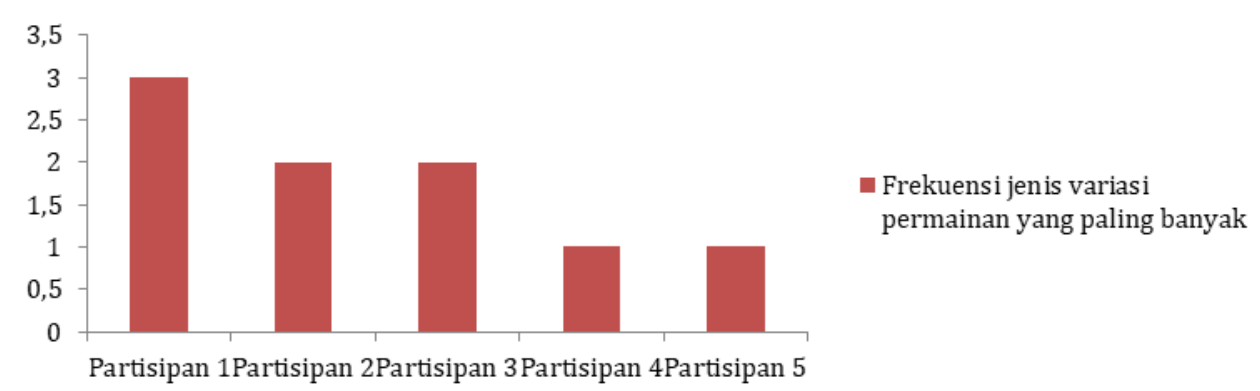

Gambar 1. Grafik variasi permainan

Hasil observasi menunjukkan masing-masing partisipan memiliki ketertarikan yang terbatas terhadap permainan yang disediakan. Partisipan lebih sering berganti permainan tertentu saja dari kelima jenis permainan yang disediakan. Partisipan pertama lebih sering memainkan tiga jenis permainan yaitu helikopter, peralatan masak dan alat kedokteran. Partisipan dua lebih tertarik dengan dua jenis permainan yaitu peralatan memasak dan peralatan kedokteran. Begitu pula dengan partisipan tiga yang lebih sering memainkan peralatan memasak dan peralatan kedokteran. Sedangkan partisipan empat memiliki ketertarikan pada peralatan memasak. Partisipan lima terlihat hanya tertarik pada satu jenis permainan, yaitu peralatan pertukangan. Namun, variasi permainan yang sering dimainkan oleh kelima partisipan tidak berarti merupakan permainan yang dimainkan dengan durasi yang paling lama. Seperti pada partisipan tiga yang terlihat paling sering memainkan variasi kedokteran dan memasak, namun berdasarkan hasil observasi partisipan tiga paling lama dalam bermain alat pancing. 


\section{Diskusi}

Secara umum hasil penelitian membuktikan bahwa terdapat hubungan antara secure attachment dan pretend play pada anak dengan ASD. Pretend play yang dimaksudkan adalah intensitas pretend play diperoleh dari frekuensi dan durasi. Sedangkan apabila berdiri sendiri antara frekuensi dan secure attachment tidak terdapat hubungan yang signifikan. Penelitian ini sesuai dengan hasil penelitian sebelumnya yang dikemukakan oleh Jarrold, Boucher, and Smith 1996 dalam Kasari et al 2013 bahwa permainan simbolik anak dengan ASD menunjukkan frekuensi yang sangat rendah atau sangat terbatas. Anak dengan ASD lebih sering melakukan permainan dengan fungsional dibandingkan dengan permainan simbolik, karena kemampuan bermain simbolik pada anak ASD inilah yang mengalami gangguan.

Permainan fungsional memfasilitasi permainan simbolik dan kemampuan bahasa pada anak dengan ASD (Papaeliou et al, 2019), namun kurang mampu ditunjukkan secara spontan (Kasari, et al 2013 dan Lam \& Susanna, 2014). Anak dengan ASD dapat menunjukkan permainan fungsional ini saat situasi terkondisi atau terstruktur. Saat kondisi dan situasi terstruktur, permainan fungsional ini hampir sama baiknya dengan kondisi anak normal meskipun penggunaan bahasa dan imajinasi belum berkembang.

Hasil observasi juga menunjukkan bahwa anak dengan ASD cenderung hanya memainkan benda atau objek sesuai dengan fungsi saja, hal ini tampak pada pola permainan partisipan satu hingga partisipan lima pada saat penelitian berlangsung.Hasil observasi ini menguatkan bahwa anak ASD hanya memilih pada permainan yang disukai, meskipun banyak alat bermain yang telah disediakan. Pada partisipan pertama memilih dan bertahan bermain dengan helikopter. Partisipan kedua memilih dan bertahan pada permainan masak-masakan, partisipan ketiga bertahan pada permainan pancing dengan durasi yang lama di antara permainan yang lain, frekuensi yang ditunjukkan pun lebih banyak pada permainan kedokteran dan masak namun durasi permainan tidak lama. Partisipan empat memilih dan bertahan pada permainan pancing, partisipan lima memilih dan bertahan pada alat pertukangan.

Hasil observasi penelitian juga menguatkan pendapat (Chan, Chen, Feng, Lee, \& Chen, 2016) bahwa anak dengan ASD tidak mampu untuk memahami mengenai perilaku pretend play sebenarnya. Pola permainan partisipan sesuai pula dengan apa yang dikemukakan oleh Weisberg (2015) bahwa pretend play adalah sebuah bentuk permainan aktif yang memunculkan kembali sebuah situasi dari kehidupan nyata seharihari, sehingga perilaku bermain yang ditunjukkan kurang kompleks dan kurang 
berinovasi. Hasil observasi juga memperlihatkan bahwa permainan yang ada dan dimainkan lebih banyak mendapatkan contoh dari ibu. Modelling dan prompting oleh ibu yang ditunjukkan pada penelitian ini, memberikan gambaran bahwa tiap partisipan mempunyai secure attachment pada sosok ibu.

Hasil wawancara kepada ibu menunjukkan bahwa kelima partisipan sehari-hari sudah dapat berkomunikasi secara verbal meskipun kalimat masih terbatas. Kelima partisipan sudah dapat mengungkapkan keinginannya secara sederhana. Keseharian kelima partisipan lebih dekat dengan ibu dan kakak atau adik di rumah. Partisipan pertama lebih sering bermain bersama ibu dan adik-adiknya di rumah dan menyukai kereta api. Partisipan memainkan dengan disusun rapi dan menjalankannya seperti film kereta api yang disukai. Partisipan satu juga bermain berpura-pura menjadi dokter dan pura-pura makan es krim. Partisipan dua lebih sering bermain bersama adik dan ibu. Keseharian partisipan dua sering mengikuti adik bermain dan berinteraksi dengan adik ketika bermain. Partisipan dua bermain masak-masakan, lempar tangkap bola dan lego bersama adik. Partisipan tiga suka bermain dokter-dokteran bersama ibu dan kakak. Partisipan tiga juga menirukan saat bermain, namun partisipan tiga mudah bosan pada permainan. Partisipan empat suka bermain boneka di rumah bersama ibu, namun juga terkadang bermain sendiri. Partisipan empat memainkan boneka dengan cara memandikan boneka, dan memberi selimut. Partisipan lima sering bermain bersama ibu di rumah. Partisipan lima suka bermain bola plastik yang dipotong dan berpura-pura menjadi buah, kemudian dipetik. Partisipan lima juga memiliki ketertarikan yang terbatas pada permainan, apabila tidak tertarik mainan hanya dilihat dan diletakkan kembali.

Penelitian ini juga melihat variasi permainan yang sering dimainkan oleh anak ASD saat melakukan pretend play. Hasil penelitian menunjukkan terdapat hubungan antara secure attachment dan variasi permainan. Hal ini dapat dilihat melalui hasil observasi dari kelima partisipan. Masing-masing partisipan memiliki ketertarikan yang berbeda pada jenis-jenis permainan yang disediakan. Pertisipan satu memiliki ketertarikan pada tiga jenis permainan dari lima jenis permainan yang disediakan, yaitu helikopter, peralatan memasak dan kedokteran. Ketiga permainan tersebut merupakan permainan yang paling sering dimainkan oleh partisipan pertama dan helikopter merupakan permainan yang dimainkan dengan durasi yang paling lama. Partisipan dua tertarik pada dua jenis permainan, yaitu alat masak dan kedokteran, alat masak merupakan permainan yang dimainkan dengan durasi paling lama. Partisipan tiga memiliki minat pada permainan alat pancing yang dimainkan dengan durasi yang paling lama. Selain itu partisipan tiga juga 
memiliki minat pada alat masak dan kedokteran yang paling sering dimainkan. Partisipan empat cukup sering memainkan alat masak, namun dengan durasi yang singkat dan bermain peralatan pancing dengan durasi paling lama. Partisipan lima lebih sering bermain alat pertukangan dan dengan durasi yang lama.

Melalui hasil wawancara menambahkan data dalam penelitian bahwa meskipun anak dengan gangguan ASD lebih tertarik pada permainan yang diminati namun ada beberapa variasi bentuk permainan yang dilakukan dan hal ini membuktikan bahwa anak ASD pun memiliki variasi dalam permainan meskipun tidak dapat bertahan lama. Seperti dikemukakan oleh Mikulincer et al (Shirvanian \& Michael, 2017), bahwa anak yang memiliki rasa secure dari orangtua mengembangkan kreativitas, lebih aktif dan konstruktif. Anak-anak yang mendapatkan secure attachment dari orangtua mulai mengembangkan kreativitas dan hal ini dapat dilihat dari para partisipan yang dapat bermain dengan orang tua, adik ataupun sendiri dengan mengembangkan sisi kreatif dengan objek-objek mainan yang ada di lingkungan sekitar.

Penelitian Naber (2008) dan Holt (2011) menguatkan hasil penelitian bahwa rasa secure memberikan anak ASD kesempatan untuk bermain lebih lama dan mengeksplorasi lingkungan yang ada di sekitar. Setiap partisipan pada sesi observasi mencoba untuk mengeksplorasi permainan yang ada meskipun akan lebih lama memainkan permainan yang disukai dan diminati. Peran orangtua dalam memahami dan menyadari dengan baik diagnosis ASD pada tiap partisipan memungkinkan menciptakan secure attachment yang lebih baik (Teague et al 2017).

Rasa secure yang diperoleh anak dari orangtua menumbuhkan rasa percaya anak kepada orangtua. Rasa percaya yang merupakan salah satu dimensi secure attachment yang membuat anak merasa akan baik-baik saja ketika mulai mengeksplorasi apa yang ada di lingkungannya. Melalui secure attachment kemandirian anak pun mulai berkembang. Anak tidak lagi merasa tergantung dengan orangtua, dapat melakukan permainan sendiri dan menikmati proses bermain tersebut. Ketika anak dapat menikmati proses bermain durasi pretend play tercatat lebih lama pada permainan yang diminati (Meins, 1997).

Anak dengan ASD yang mendapatkan secure attachment juga memperoleh dukungan dan support yang positif dari orangtua sebagai bentuk responsif orangtua terhadap anak sehingga anak mendapatkan stimulasi secara sosial dan kognitif sebagai bentuk interaksi hal ini pun berkorelasi dengan pretend play (Hobson et al, 2017). Pada hasil observasi juga menunjukkan interaksi antara ibu dan partisipan ketika ibu bertanya mengenai permainan yang sedang dimainkan. Pada partisipan pertama memiliki inisiatif untuk 
memulai berinteraksi dengan ibu, dengan cara mengatakan nama alat permainan yang dimainkan pada ibu. Partisipan pertama juga mengikuti instruksi yang diberikan oleh ibu. Partisipan kedua juga menunjukkan interaksi bersama ibu saat bermain dengan mengikuti instruksi dari ibu dan menjawab pertanyaan dari ibu. Pada partisipan tiga menunjukkan interaksi saat bermain bersama ibu dengan sama-sama menghitung saat memancing ikan, menirukan ibu, mengikuti instruksi dari ibu dan menjawab pertanyaan dari ibu. Partisipan empat menunjukkan interaksi dengan mengikuti apa yang dikatakan ibu dan apa yang diarahkan oleh ibu, begitu pula dengan partisipan lima. Kelima partisipan juga menunjukkan ekspresi senang ketika diberikan dukungan oleh ibu saat bermain bersama.

Modelling dan prompting termasuk di dalamnya interaksi baik secara verbal maupun nonverbal oleh sosok ibu terhadap para partisipan mengambil peran penting dalam mengajarkan anak bermain pretend play (Szabó, 2014). Anak-anak dengan ASD yang mempunyai secure attachment juga menunjukkan bahwa mereka lebih sensitif dan responsif dibandingkan anak ASD yang mempunyai kelekatan tidak aman (Crowell, Keluskar, \& Gorecki, 2018).

\section{Simpulan}

Berdasarkan hasil penelitian dan diskusi maka disimpulkan bahwa pretend play pada anak dengan ASD dapat dikembangkan melalui secure attachment yang baik antara orangtua dan anak. Rasa aman memberikan kesempatan anak dengan ASD untuk bermain lebih lama pada permainan pretend play meskipun bentuk permainan yang ditunjukkan oleh para partisipan masih masuk dalam permainan fungsional.

Saran untuk penelitian lebih lanjut bahwa secure attachment hanya salah satu bagian yang mempengaruhi pretend play, masih ada faktor yang lain mempengaruhi pretend play. Hal ini dapat menjadi himbauan bagi penelitian selanjutnya. Saran untuk orangtua lebih dapat mengembangkan lagi secure attachment kepada anak agar dapat mengembangkan kemampuan bermain sebagai sarana bersosialisasi anak ASD terhadap lingkungan.

Keterbatasan penelitian ini adalah mengenai waktu observasi. Waktu observasi pada penelitian ini hanya dilakukan selama satu kali, dikarenakan situasi pandemi Covid19.

\section{Kepustakaan}

Association, A. P. (2013). Diagnostic And Statistical ManualOf Mental Disorders. Fifth Edition. Washington DC: American Psychiatric Publishing. Azwar, Saifuddin. 2013. Penyusunan Skala Psikologi. Yogyakarta :Pustaka Pelajar. 
Barton, PhD, BCBA-D, E. E., \& Pavilanis, MS, R. ( 2012). Teaching Pretend Play to Young Children With Autism. YOUNG EXCEPTIONAL CHILDREN. https://citeseerx.ist.psu.edu/viewdoc/download?doi=10.1.1.903.661\&rep=rep1\&ty pe $=$ pdf.

Benson, J,Nicka, M \& Stern, P (2006). How Does a Child with Sensory Processing Problems Play. The Internet Journal of Allied Health Sciences and Practice. https://nsuworks.nova.edu/cgi/viewcontent.cgi?referer=https://www.google.com/ \&httpsredir $=1 \&$ article $=1121 \&$ context=ijahsp

Bergen, D. (2002). The Role of Pretend Play in Children's Cognitive Development. Early Childhood Research \& Practice.https://eric.ed.gov/?id=ED464763

Besio, S., Bulgarelli, D., Stancheva-Popkostadinova, V., (2017). Play Development in Children with Disabilities ; Play in Children with Autism Spectrum and Other Neurodevelopmental Disorder. De Gruyer Open Ltd, Warsaw/Berlin. https://www.hetsl.ch/fileadmin/user upload/rad/laress/observatoiretsa/9783110522143 - Play development in children with disabilties.pdf

Campbell, S. B., Leezenbaum, N. B., Mahoney, A. S., Moore, E. L., \& Brownell, C. A. (2017). Pretend Play and Social Engagement in Toddlers at High and Low Genetic Risk for Autism Spectrum Disorder. J Autism Dev Disorder. . https://scihub.do/10.1007/s10803-016-2764-y

Chan, P. C., Chen, C. T., Feng, H., Lee, Y. C., \& Chen, K. L. (2016). Theory of Mind Deficit Is Associated with Pretend Play Performance, but Not Playfulness, in Children with Autism Spectrum Disorder. Hong Kong Journal of Occupational Therapy. https://www.sciencedirect.com/science/article/pii/S1569186116300249

Cohen, D. (2006). The Development of Play. Third Edition. New York: Routledge.

Creswell, J.W. (2009). Research Design, Qualitative, Quantitative, and Mixed Methods Approaches.(edition 3). Los Angeles : SAGE

Crowell, J. A., Keluskar, J., \& Gorecki, A. (2018). Parenting Behavior and The Development of Children with Autism Spectrum Disorder. Comprehensive Psychiatry.https://www.sciencedirect.com/science/article/pii/S0010440X1830192 5https://www.sciencedirect.com/science/article/pii/S0010440X18301925

Desiningrum, D. R. (2016). Psikologi Anak Berkebutuhan Khusus. Yogyakarta: Psikosain.

Doody, K.R \& Mrertz,J (2013). Preferred play Activities of Children with Autism Spectrum Disorder in Naturalistic Settings. North American Journal of Medicine and Science. https://naims.com/index.php/naims/article/view/190/175

Fonagy, P., Steele, M., Steele, H., Moran, G. S., \& Higgitt, A. C. (1991). The Capacity for Understanding Mental States: The Reflective Self in Parent and Child and Its Significance for Security of Attachment. Infant Mental Health.https://onlinelibrary.wiley.com/doi/abs/10.1002/10970355\%28199123\%2912\%3A3\%3C201\%3A\%3AAIDIMHJ2280120307\%3E3.0.CO\%3B2-7

Frost, W. d. (2008). Play and Child Development. Pearson.

George, C (2014). Attachment Theory ; Implications for Young Children and Their Parent's. In K. Brandt, B. Perry, \& E. Tronick (Eds.). Infant and early childhood mental health (pp. 97110). Arlington,VA:American Psychiatric Publishing. https://www.researchgate.net/publication/261436928 Attachment theory Implica tions for young children and their parents/link/580644c108ae03256b76dd1e/do wnload

Goldstein, J. (2012). Play in Children's Development, Health and Well -Being Boulevard de Waterloo 36: Toy Industries of Europe (TIE). Diambil dari : https://www.ornes.nl/wp-content/uploads/2010/08/Play-in-children-sdevelopment-health-and-well-being-feb-2012.pdf 
Hobson A.J, Laura Tarver.,Beurkens Nicole., R. Peter Hobson. (2015). The Relation Between Severity of Autism and Caregiver-Child Interaction : A Study in the Context of Relationship Development Intervention. J. Abnorm Child Psychol. https://scihub.do/10.1007/s10802-015-0067-y

Holt, C.E (2011). Child-Caregiver Play and Attachment in Pre-School Autism, A Longitudinal Investigation : A Thesis Submitted to The University \& Manchester, for The Degree of Doctorate of Philosophy in the Faculty of Medical and Human Sciences.

https://www.research.manchester.ac.uk/portal/files/54513482/FULL TEXT.PDF

Howard, J., Milest, G. E., Rees-Davies, L., \& Bartenshaw, E. J. (2017). Play In Middle Childhood : Everyday Play Behaviour and Associated Emotions. CHILDREN \& SOCIETY, 1-12. https://sci-hub.do/10.1111/chso.12208

Jorgenson,E.J (2017). Pretend Play and Children with Autism Spectrum Disorder ; Deficits and Intervention. Appalachian State University. Thesis. https://libres.uncg.edu/ir/asu/f/Jorgenson,\%20Emily\%202017.pdf

Kasari,C., Ya-Chih Chang, \& Stephanie , P., (2013). Pretending to Play or Playing to Pretend: The Case of Autism. American Journal of Play; Volume 6 No. 1. https://www.ncbi.nlm.nih.gov/pmc/articles/PMC4662258/

Lam Y.G and Susanna S.Y, 2014. Symbolic Play in Children with Autism. https://www.researchgate.net/publication/280094241 Symbolic Play in Children with Autism

Lifter, K., Mason ,E.J., \& Barton, E.E (2011). Children's Play : Where We Have Been and Where We Could Go. Journal of Early Intervention. https://scihub.do/https://doi.org/10.1177/1053815111429465

Malekpour, M. (2007).Effect of Attachment on Early and Later Development http://www.sakkyndig.com/psykologi/artvit/malekpour2007.pdfh

Meins, E. (1997). Security of Attachment and The Social Development of Cognition. New York : Psychology Press, Ltd.

Naber, F. B., Bakermans-Kranenburg, M. J., IJzendoorn, M. H., Swinkels, S. H., Buitelaar, J. K., Dietz, C., et al. (2008). Play Behavior and Attachment in Toddlers with Autism. J Autism Dev Disord. https://www.ncbi.nlm.nih.gov/pmc/articles/PMC2335292/

Papaeliou C.F, Kokonitsa Sakellaki and Asinenia Papoulidi, 2019. The Relation Between Functional Play and Other Form of Cooperation and Word Learning in ASD. Int. Arch Disord 2019, Volume 2. https://www.researchgate.net/publication/332525571 The Relation between Fun ctional Play and Other Forms of Cooperation and Word Learning in ASD

Papalia, D.E., Olds, S.W. and Feldman, R.D. (1999). A child's world: Infancy through adolescence. (pp.245-252). The McGrow Hill Companies, Inc. New York, USA.

Prasetyono , D. S. (2008). Serba-Serbi Anak Autis. Jogjakarta: Diva Press.

Runcan, P. L., Petracovschi, S., \& Borca, C. (2012). The Importance of Play in TheParentChild Interaction. Procedia - Social and Behavioral Sciences , 795 - 799.https://scihub.do/https://doi.org/10.1016/i.sbspro.2012.05.201

Safaria, T. (2005). Pemahaman Baru untuk Hidup Bermakna bagi Orangtua Autisme. Graha Ilmu.

Scholastic-parents staff, (2020). The Importance of Pretend Play :Imagination-driven play builds your young child's developmental

skills.https://www.scholastic.com/parents/kids-activities-andprintables/activities-for-kids/arts-and-craft-ideas/importance-pretend-play.html

Sivaratnam, C. S., Newman, L. K., Tonge, B. J., \& Rinehart, N. J. (2015). Attachment and Emotion Processing in Children with Autism Spectrum Disorders: Neurobiological, Neuroendocrine, and Neurocognitive Considerations. Review Journal of Autism and 

https://www.researchgate.net/publication/275257010 Attachment and Emotion Processing in Children with Autism Spectrum Disorders Neurobiological Neuroen docrine and Neurocognitive Considerations

Shirvanian, N \& Michael,T.(2017). Implementation of attachment theory into early childhood s. Settings. The International Education Journal: Comparative Perspectives Vol. 16, No. 2, 2017, pp. 97-115. https://openjournals.library.sydney.edu.au/index.php/IEI

Sugiyono, (2016).Metode Penelitian Kuantitatif, Kualitatif dan R\&D. Bandung: Alfabeta.

Szabó, M. K. (2014). Patterns Of Play Activities In Autism And Typical Development. A Case Study. Procedia - Social and Behavioral Sciences 140, 630 637.https://reader.elsevier.com/reader/sd/pii/S1877042814034090?token=2B42 2AE258EE6B4CE49633A2B3BFF022BA043BEE7DFE9CA79EF2649D8F55564E2D3 BCF7BB4D906EB15571A5462089558\&originRegion=eu-west1\&originCreation $=20210518145843$

Tedjasaputra, M. S. (2001). Bermain, Mainan dan Permainan untuk Pendidikan Usia Dini. Jakarta: PT. Grasindo.

Teague, S. J., Gray, K. M., Tonge, B. J., \& Newman, L. K. (2017). Attachment in children with autism spectrum disorder: A systematic review.Research in Autism Spectrum Disorders, 35-50. https://sci-hub.do/https://doi.org/10.1016/j.rasd.2016.12.002

Watson, L.R. ( 2011). Enhancing Pretend Play Skills in Preschoolers with Autism Spectrum Disorders. Case Studies by ASHA Professional Development. University of north Carolina at Chapel Hill. https://www.kyrene.org/cms/lib/AZ01001083/Centricity/Domain/3679/Enhanci ng\%20Pretend\%20Play\%20Skills\%20Handout.pdf

Weisberg, D. S. (2015). Pretend Play. Wiley interdisciplinary reviews. Cognitive science.https://www.researchgate.net/publication/271590259 